\title{
Risk Code
}

National Cancer Institute

\section{Source}

National Cancer Institute. Risk Code. NCI Thesaurus. Code C95347.

A coded value specifying the risk. 